\title{
The Influence of Attitude, Interest, Teachers and Peers on Entrepreneurial Career Intention
}

\author{
Radin Siti Aishah Radin A. Rahman*, Norasmah Othman, Nor Baizura Muhamad Talkis \\ Faculty of Education, Universiti Kebangsaan Malaysia, 43600 Bangi, Malaysia
}

Received August 18, 2020; Revised October 7, 2020; Accepted October 30, 2020

\begin{abstract}
Cite This Paper in the following Citation Styles
(a): [1] Radin Siti Aishah Radin A. Rahman, Norasmah Othman, Nor Baizura Muhamad Talkis, "The Influence of Attitude, Interest, Teachers and Peers on Entrepreneurial Career Intention," Universal Journal of Educational Research, Vol. 8, No. 11A, pp. 78 - 88, 2020. DOI: 10.13189/ujer.2020.082110.

(b): Radin Siti Aishah Radin A. Rahman, Norasmah Othman, Nor Baizura Muhamad Talkis (2020). The Influence of Attitude, Interest, Teachers and Peers on Entrepreneurial Career Intention. Universal Journal of Educational Research, 8(11A), 78 - 88. DOI: 10.13189/ujer.2020.082110.
\end{abstract}

Copyright $\bigcirc 2020$ by authors, all rights reserved. Authors agree that this article remains permanently open access under the terms of the Creative Commons Attribution License 4.0 International License

\begin{abstract}
The purpose of this study is to identify the influence of interest, attitude, teachers and peers towards entrepreneurial career intention of religious secondary school students in Malaysia. The objectives of this study are to identify the level of interest, attitude, teachers' guidance, peers and behaviour towards students' entrepreneurial career intention, and to identify the influence of attitude, interest, teachers' guidance, and peers towards student behaviour on entrepreneurial career intention. This quantitative study uses a survey design involving 328 religious secondary school students in the Sepang district based on multistage sampling starting from stratified random sampling to simple random sampling. The result of the study showed that the domains of attitude, interest, teachers' guidance, peers and behaviour of entrepreneurial career intention are at a moderately high level. The result of the analysis also revealed that the domain of attitude, interest, teachers' guidance and peers have significant influence over behaviour on entrepreneurial career intention at 62.6 percent. The domain of interest is the best way to predict the behaviour of students' entrepreneurial career intention compared to other domains. On the other hand, the domain of attitude is the worst in predicting the behaviour of entrepreneurial career intention. These findings clearly indicate that religious secondary school students have a moderately high tendency to choose entrepreneurship as a career which is driven by interest, teachers' guidance and peers. The implications of the study also contribute to the applicability of the Theory of Planned Behaviour by Ajzen (1991).
\end{abstract}

Meanwhile, schools need to play a role nurturing entrepreneurial attitudes through formal and informal education continuously.

Keywords Attitudes, Interests, Teachers' Teaching, Peers and Entrepreneurship Career Behaviour, Religious Secondary School Students

\section{Introduction}

The Malaysia Education Blueprint 2013-2025 aims to strengthen the development of vocational education by providing the necessary practical skills, especially in the field of entrepreneurship, and produce students with high leadership skills. Meanwhile, The Secondary School Standard Curriculum (KSS) was introduced to emphasise on High Level Thinking Skills (HTLS) to encourage students to think creatively and critically when solving problems. Thus, it is seen that this new curriculum is able to help students in developing their potential and entrepreneurial attitudes as early as their secondary school years. Secondary schools in Malaysia are a place to nurture young people who can adopt a positive lifestyle and contribute to the country's economic progress [1]. In order to produce better people, one of the goals set by the government for secondary schools is the establishment of entrepreneurship clubs through the entrepreneurship cocurriculum. An entrepreneurship club gives secondary 
school students early exposure to the real entrepreneurship world and helps the government to create a commercialised community and a Bumiputera Industry. The contribution and role of entrepreneurial activities are known to be catalysts of the country's economic growth and act as the main driver in increasing the level of innovation, creativity and competitiveness of the country on the world stage [2]. Students are trained to be creative and innovative, foster their entrepreneurial interest and create job opportunities. This will indirectly produce students who would be directly involved and actively manage their own business [3]. Therefore, the government encourages students to be engaged in various entrepreneurship programs such as training, seminars, short-term courses, conferences and other activities to develop entrepreneurial behaviour among students, thereby developing the economy of the country as a whole. As a proof of its success, the Young Entrepreneur Programme organised in secondary schools successfully cultivates the value of entrepreneurship as the level of entrepreneurship value is high.

The fact is, the level of students selecting the entrepreneurship field has been found to be low [4-7]. Moreover, entrepreneurship as a career is not a popular option among graduates of higher education public institutions [8]. In addition, youth unemployment at a young age has a serious long-term negative impact on their income and risks their marketability after obtaining a university degree [9]. Thus, career dependence in the public sector, private sector, non-governmental organisations and other sectors indirectly affects the unemployment rate of 25.3 percent of graduates at the undergraduate level [10]. This shows that students are still unaware of entrepreneurial career opportunities and fail to realise the abundance of opportunities that exist in the era of technological development [11]. More specifically, the younger generation does not seize business opportunities that exist as a result of current technological developments where these opportunities can be used as alternative careers.

The unwillingness to take the opportunity to make entrepreneurship a career of choice causes this career to be unpopular [11-14]. The existence of negative perceptions towards the field of entrepreneurship among students is also one of the factors students are not interested in venturing into the field of entrepreneurship [15]. Thus, students who have negative thoughts on entrepreneurship will lose confidence and be unaware of the opportunities that exist around them.

In an effort to support and encourage students to venture into entrepreneurial careers, the teacher's role is one of the solutions. Teachers play the main role of equipping the younger generation with business skills as well as entrepreneurial personality traits. According to Nurul Izzati [16], competent teachers are necessary in accomplishing this goal, and quality entrepreneurship education also needs to be implemented to ensure students have a positive perception of entrepreneurship which ultimately increases the level of marketability of students in the employment industry [17]. This means that negative perceptions among students towards entrepreneurial careers need to be altered so that the field of entrepreneurship becomes a career aspiration and a popular choice in the future.

Other studies have stated that most teachers are not experts, and do not have entrepreneurial skills and training [18]. Findings in the Competitiveness and Innovation Framework Programme 2007-2013 comprising of 26 countries which are Belgium, Bulgaria, Czeck Republic, Denmark, Germany, Spain, Estonia, France, Italy, Cyprus, Lithuania, Latnia, Luxembourg, Hungary, Malta, Norway, Austria, Poland, Slovakia, Slovenia, Finland, Sweden and the United Kingdom, showed that there are gaps or constraints in implementing entrepreneurship programmes. These constraints include teachers lacking entrepreneurship knowledge, incompetent teachers, no involvement from individuals from the entrepreneurship industry, lack of practical elements and limited student participation and implementation of entrepreneurship programmes which are not associated with specific training or professions [19]. Furthermore, almost half of those countries requested that special training for selfemployment be applied in all entrepreneurship courses. Meanwhile in Malaysia, the government offers entrepreneurship training to teachers, but the training provided does not use a systematic approach [16].

Next, some researchers support the argument that peers influence an individual's attitudes and behaviours. According to Noor Erma [20], if students are friends with students who are interested in business, the student's tendency to get involved in business is higher. However, the aspect of peers and its relevance to entrepreneurial behaviour has rarely been studied. Very few literature reviews have been done on the aspect of peer influence on one's entrepreneurial potential. Many researchers focus more on the study of entrepreneurial concepts, internal factors, characteristics and processes that occur in entrepreneurship and emotional intelligence.

According to the problems mentioned above, this study aims to identify the influence of attitudes, interests, teachers' guidance and peers on entrepreneurial career intention. It is hoped that this study would reduce the research gap that exists as very few studies have been conducted on teachers' guidance and peer influence on the potential of entrepreneurship [21]. By identifying the problem, it is hoped that that the study would provide clearer and more accurate ideas and references for stakeholders and anyone interested in a variety of appropriate initiatives to achieve the government's aspirations in producing more young entrepreneurs. In fact, strong cooperation and understanding are expected to raise awareness and intention to a higher level among students to choose entrepreneurship as a career in the future. Thus, 
research is needed to identify the influence of attitudes, interests, teachers' guidance and peers on entrepreneurial behaviour. The objectives of this study are to identify the level of attitudes, interests, teachers' guidance, peers and students' entrepreneurial career intention behaviour and to identify the influence of attitudes, interests, teachers' guidance and peers on students' entrepreneurial decision behaviour. Meanwhile, the research questions are the following:

1) What is the level of attitude, interest, teachers' guidance, peers and students' entrepreneurship career intention behaviour?

2) To what extent do attitude, interest, teachers' guidance and peers influence students' entrepreneurial decision behaviour?

\section{Literature Review}

\subsection{Attitude, Interest, Teachers' Guidance, Peers and Entrepreneurial Career Intention}

The domains of producing creative, innovative and firstclass minded students' need to be examined in order to evaluate to what extent do they influence and affect students. Attitude, for example, is a domain that is often used to describe entrepreneurial behaviour. Researchers [22-25] found that attitude is strongly related to entrepreneurship. According to them, the attitude of an entrepreneur is always focused on the result of the business while always ensuring that each of their businesses is profitable. Other studies such as [26-28] agreed that attitudes influence entrepreneurial career intention. This trend means that entrepreneurs have self-efficacy [29]. Self-efficacy is having self-confidence, that is, knowing oneself well, believing oneself and having the ability to see one's strengths and weaknesses accurately [29]. This statement is very much in line with the attitude influencing the choice of entrepreneurial career. Only individuals who have self-efficacy have the courage to choose entrepreneurship as a career. This shows that entrepreneurs need to be confident, positive and always believe in themselves. A study by Ravi [30] showed that attitudes have a significant variant value towards entrepreneurship, which influences entrepreneurial career intention behaviour by 55.9 percent. Reinforcing the discussion, researchers [31] found that attitude is significant as a predictor of entrepreneurial career intention behaviour with an influence of 22 percent $\left(R^{2}=0.22\right)$. The findings of Zairon's [32] study found that the variance value for attitudes is 67 percent $\left(R^{2}=0.67\right)$, hence the domain of attitude is the main predictor of entrepreneurial intentions of community college students.

Furthermore, the domain of interest predictors on average shows a trend that is almost in line with each of the findings of previous studies. A study on high school students found that the level of interest of entrepreneurial career behaviour is at a moderately high level $[33,34]$. Other studies stated that students at higher education institutions have a positive attitude towards entrepreneurship, but are not interested enough to venture into the field [18]. This statistical number is similar to a study by Johansen [79], which found that between 48 percent to 50 percent of secondary school students in Norway are interested in entrepreneurship. However, there is a positive relationship between interest and entrepreneurial career $[18,33,35]$. To further strengthen the discussion, a study by Norfadhilah and Halimah [18] found that interest significantly influenced the entrepreneurial career intention of students by 70.0 percent $\left(\mathrm{R}^{2}=0.70\right)$. These literature review trends show that students should be given the opportunity to gain experience in entrepreneurship. Through the experience gained, students become more confident and begin to form positive interests and perceptions about entrepreneurship [36,37]. Students should be able to interview successful entrepreneurs, visit trade fairs and do a variety of activities related to entrepreneurship. These activities have the potential to influence behaviour towards entrepreneurship.

Teachers play an important role in the implementation of a curriculum innovation. Teachers have different backgrounds, teaching abilities and capabilities, attitudes, knowledge and skills which determine the level of guidance being provided for students towards entrepreneurship [38]. The literature review on teachers' guidance towards various entrepreneurial career intentions points to the fact that teachers take on an important task as an implementing agent to influence students to choose entrepreneurship as a career field. Previous studies found that teachers' guidance contributes 48.8 percent of the variance to entrepreneurial career intention behaviour $\left(\mathrm{R}^{2}=0.488\right)$ [18]. This moderate percentage should be given attention, as this predictor domain is directly related to the intention of entrepreneurial careers among students. Teachers need to diligently master the content, understand the appropriate methods of approach, understand students well, always be positive and provide a high commitment in teaching business subjects until they are able to influence students' entrepreneurial career intention.

\subsection{Theory of Planned Behaviour, Ajzen (1991)}

The Theory of Planned Behaviour [39] is used as a basic theory that has significant applicability to entrepreneurial career intention. This theory is also often used by many researchers to examine a person's behaviour and inclinations. The search for the keywords "Ajzen Planned Behaviour Theory" using Google Scholar was referenced 4550 times in 2010 compared to 22 citations in 1985 [40]. This explains that Ajzen's theory has achieved the highest 
scientific impact score among social psychologists in the United States and Canada [39]. The Theory of Planned Behaviour explains that the proposed behaviour is influenced by attitudes, subjective norms and perceived behaviour control. These three main factors are interrelated and are used to predict and explain the proposed behaviour of an individual. In the context of this study, behaviour is a product of the dynamic interaction between entrepreneurial attitudes, control over entrepreneurial behaviour and the social norms of society and culture. Apart from these factors, behaviour also involves cognitive factors and psychological factors [40]. Examples of cognitive factors are assessing abilities, values and social support. Meanwhile, psychological factors consist of motivation, emotions, thoughts and tendencies during entrepreneurial activities.

The factor of attitude towards behaviour aims to identify perceptions of self-desire to actively engage in a behaviour. This attitude depends on the expectations and beliefs about the personal effects of the behaviour. Ajzen [39] explains that individuals would evaluate whether or not they are happy performing such behaviours. Good assumptions about appraisal will further increase the level of desire to become an entrepreneur, while bad or negative appraisal results in behaviour not being demonstrated [41]. Thus, attitude refers to an assessment of a psychological object, for example good - bad, beneficial - unbeneficial and pleasant - unpleasant [42]. This attitude predictor refers to the level of individual evaluation of whether or not the selfbehaviour is fun.

Subjective norms are defined as individual beliefs about what others think about whether they can demonstrate such behaviour or not [43]. For example, this can refer to their family's perception towards them. Subjective norms can have a strong influence on one's desire if the individual has a high locus of internal control and also if he has a high orientation to act. The most influential subjective norms are family members, important people, friends, 'role models' and mentors [44]. A predictor of perceived controlled behaviour refers to an individual's perception of whether or not it is easy to perform a behaviour [39,43]. This evaluation depends on one's external and internal factors such as experience, skills, resources and opportunities. The higher an individual's behavioural control, the higher his or her perception of opportunity [45]. In other words, if a person has control over those factors, then the intention to act on the behaviours will be weak.

In this context, the predictor domain of attitudes, interests, teachers' guidance and peers were used to study and predict entrepreneurial behaviour among students. The intention of this domain is related to the predictive factors proposed by Ajzen [39] which are attitudes, subjective norms and perceived control behaviours. The individuals have an interest and plan to start a business while seeking the opinions and advice from parents, siblings, teachers and friends about the benefits and advantages of doing business. The opinions received from these people will influence their perception of how easy or difficult an entrepreneurial career is and ultimately influence their decision of whether or not to start venturing into the entrepreneurship field and start a business. If a person has a high level of behaviour control, then his perception of the entrepreneurial career will also be high and will eventually choose entrepreneurship as a career and vice versa.

\section{Methodology}

This study uses a quantitative design survey that is analysed descriptively and inferentially. Multistage sampling involves stratified random sampling according to selected zones to determine the study sample. After selecting the zones, a simple random voting technique is done to obtain the final sample based on the data source obtained from the Education Office. A total of 2047 business students in religious secondary schools in the district of Sepang, Selangor, Malaysia were involved in the study. This sample size was selected based on a study by Krejcie and Morgan [46] who recommended a sample size of at least 328 students. This sample size was selected because the business subject is offered to all students as an elective. Thus, this group of students was considered suitable as they fit the requirements of the study sample. In addition, they have experience being involved in entrepreneurship programmes organised by the school. Therefore, the perception of these students is very much needed in the study in order to predict entrepreneurial career intention behaviour among secondary school students.

Next, this study uses a questionnaire. This questionnaire is divided into six parts which are Part A, the demographic profile of respondents adapted from Rosna [40]; Part B, the domain of attitude towards entrepreneurship adapted from Nor Aishah \& Yap Poh Moi [47]; Part C, the interest domain adapted from Zaimah [48]; Part D and E, the domain of teachers' guidance and peers adapted from Quek Miow Leng [49]; and Part F, the domain of entrepreneurial career intention behaviour adapted from Nor Aishah [5052].

Next, the process of validating the content was implemented by taking the consent of experts of the entrepreneurship field into account. Experts were selected based on several criteria such as work experience and expertise in the field of entrepreneurship. To ensure face validity, language teachers checked the questionnaire to ensure that the order of sentences of each item in the instrument is correct. All views and opinions were taken into account to improve the quality of the items and domains. The credibility process was carried out on 30 students who took business as an elective subject at one of 
the religious secondary schools in Sepang district, Selangor. The pilot test results showed that there was a correlation between the score of each item with a total score exceeding 0.30 and a Cronbach Alpha value for each domain exceeding 0.80 . This shows that the validity and credibility of this instrument are high and can be used for the actual study.

The descriptive analysis in this study involves data to identify the first research objective, which are the level of attitude, interest, teachers' guidance, peers and behaviour of entrepreneurial career intention. This data analysis is reported in the form of frequency, percentage, mean score and standard deviation. The level of interpretation is determined by referring to the mean value based on a study by Norasmah [53] which is widely referred to in entrepreneurship studies. The mean value of $1.00-2.00$ is low, 2.01- - 3.00 is moderately low, $3.01-4.00$ is moderately high and $4.01-5.00$ is high. Inference analysis refers to the second research objective involving a multiple regression analysis on the influence of the predictor domain on entrepreneurial career intention behaviour. This analysis was carried out after meeting the assumed requirements in this analysis.

\section{Results and Discussion}

This section discusses the findings of descriptive and inferential research analysis to answer the research questions. The results of this data analysis are discussed and supported by the findings of previous studies.

\subsection{Research Question 1}

What is the level of attitude, interest, teachers' guidance, peers and entrepreneurial career intention behaviour?

To answer this research question, a total of 50 items were used to measure the level of each domain; attitudes (10 items), interests (10 items), teacher education (10 items), peers (10 items) and student entrepreneurial career intention behaviour (10 items). Each item was measured using a five-point Likert scale (strongly disagree, disagree, moderately disagree, agree and strongly agree) and the mean score value of each domain was based on Norasmah's [53] interpretation. Overall, the domain levels of entrepreneurial career intention behaviour are summarised in Table 1.

The attitude domain $($ Mean $=3.91, \mathrm{SD}=0.41)$ recorded the highest score compared to the interests, teachers' guidance, peers and entrepreneurial career intention behaviour of religious secondary school students despite being in the same moderately high-level category. This finding is supported by [54,55] who obtained the same score. The value of this score indicates that secondary school students have a good and positive perception of entrepreneurial career. This analysis shows that secondary school students have a good and positive attitude towards a career in entrepreneurship. However, the findings of the study are contrary to a study by [56] who recorded a high level of attitude. This proves that the entrepreneurial career has succeeded in gaining favour among secondary school students in Malaysia. Positive confidence in one's ability will further increase motivation to achieve a goal [57]. The findings of this study also show that while students already have confidence and believe in entrepreneurship, these factors are not sufficient enough for them to start a business. This matter needs to be taken into account because the findings of Mustapha [58], related to the aspirations of students' entrepreneurial career found that attitude, specifically self-confidence, is a characteristic that influences the choice of entrepreneurial career among students. Therefore, his findings also support this study.

Next, the level of interest among religious secondary school students is moderately high (Mean $=3.64, \mathrm{SD}=$ 0.57). This shows that the majority of secondary school students show commitment and intention to take the first step in venturing into the field of entrepreneurship. This finding is in line with the findings of a study on 91 students of commerce secondary schools in SMK Section 24 (C) which showed that the level of interest in entrepreneurial career behaviour is at a moderately high level $[33,34]$. This shows that students show interest in becoming entrepreneurs. At school level, knowledge and skills acquired can spark interest in entrepreneurship. However, the entrepreneurship education curriculum at form 4 and form 5 levels only covers 23 percent of the entire commerce syllabus [59]. Thus, it is assumed that the exposure received by the students is not enough to create a concrete sense of interest in entrepreneurship. Therefore, it is suggested that the intention of elective subjects such as Business should go through a certain filtering process such as only selecting students who are interested in becoming entrepreneurs. The use of social media regardless of age is able to positively expand the horizons of students' thinking [40] as well as successfully increase motivation and interest in entrepreneurship which ultimately make them choose entrepreneurship as a career. This is emphasised because interests and inclinations need to be cultivated so that the intention of entrepreneurial career can be nurtured and developed and finally, learning objectives can be achieved. Students with high interest are always striving and diligently improving their self-performance. Their satisfaction can only be achieved when they learn and understand entrepreneurship.

Next, the interpretation of the score shows that the level of teachers' guidance in secondary schools is at a moderately high level that is (Mean $=3.70, \mathrm{SD}=0.63$ ). This means that teachers need to always learn something so that their knowledge is always relevant to the current situation and needs. The findings of this study further 
strengthen the results of previous studies where the education level of Commerce teachers is at a moderately high level [60]. Similarly, the findings of [61] explains that teachers play a role in influencing students' entrepreneurial careers. Meanwhile, the findings of a study by Zulfaka [62] provide better findings where it was shown that teachers' guidance on entrepreneurship is high. This finding is also in line with the study of Nor Aishah and Yap [47]. It proves that teachers have the ability and skills in the learning and teaching process for business subjects. Appropriate knowledge, skills and approaches possessed by teachers are very important to stimulate and attract students to ensure that the teaching and learning process is excellent. The results of this study also require teachers to master the strategies of diversifying teaching methods. Among the strategies proposed are problem-based learning, constructivism, discovery inquiry, decision making and project-based learning. In the process of building skills in critical thinking, problem solving among business students becomes easier. This could lead to more students understanding the concept of entrepreneurship and eventually choosing entrepreneurship as a career. According to a study by Abaho, Olomi \& Urassa [63], entrepreneurship students' most favourable methods include interacting with successful entrepreneurs, selfreading, handouts and presentation. Meanwhile, the most unfavourable method is playing business simulation games. Teachers need to use methods and approaches appropriate to students' abilities to stimulate and attract interest in learning [64]. Therefore, teachers need to constantly learn so that their knowledge is always relevant to the current situation and needs. Teachers also need to know how to manage classrooms and learn about student learning modes as well as appropriate teaching methodologies and technology used.

The domain of peers is at a moderately high level (Mean $=3.46, \mathrm{SD}=0.51)$. This shows that peers are able to influence an individual if they have the same interests and are able to work together and also motivate each other [65]. These findings further strengthen the findings of [65] towards 140 students who took the subject of Trade and Entrepreneurship. They reported that the level of peer influence was also moderately high. This finding is also in line with [65], where the level of peers influencing students' interest in the field of entrepreneurship was found to be at a moderate level. This means that peers play an important role in influencing a student's decision in choosing entrepreneurship as a career. Praise and appreciation from friends would give an individual self-confidence and strength to venture into the field of entrepreneurship. This benefits the students and encourages them to learn more diligently and persistently about entrepreneurship. Indirectly, students strive to improve their knowledge related to entrepreneurship when they have similar opinions with their peers about entrepreneurship, especially if they get good feedback and feel comfortable and secure working as an entrepreneur [66]. The findings of this study are similar to the findings of studies by $[67,68]$.

The domain of entrepreneurial choice intention behaviour recorded a moderately high level (mean $=3.41$, $\mathrm{SD}=0.67)$. These findings show that most secondary school students have the potential to become entrepreneurs. They only need guidance and enhancements in nurturing their entrepreneurship skills as they are not yet able to generate and evaluate ideas that can be realised into a business opportunity [69]. This finding is supported by [11] who also stated that the level of entrepreneurial career intention behaviour is at a moderately high level. These findings illustrate that the average secondary school student has the intention, desire and inclination to venture into the field of entrepreneurship after graduation or during their university studies. This means that only entrepreneurship nurturing strategies need to be revised and improved. This finding is also supported by $[44,59,70]$. They are of the opinion that entrepreneurship involves cognitive operations as a result of interaction with the environment. Therefore, because time and certain situations can cause behavioural change and decrease in interest towards entrepreneurship, the entrepreneurial career intention behaviour of secondary school students needs to be further polished and nurtured from time to time so that the goal of producing many young entrepreneurs in Malaysia is achieved [71]. Schools, for example, need to hold various entrepreneurial activities to encourage students to start small businesses [72]. Students also need to be equipped with entrepreneurial knowledge and skills to start a business [73]. Thus, it is a challenge for a school to develop students' potential as well as to motivate students to wisely identify the opportunities available and eventually choose entrepreneurship as a career in future.

Table 1. Level of attitude, interest, teachers' guidance, peers and entrepreneurial career intention behaviour

\begin{tabular}{clccc}
\hline No & Domain & $\begin{array}{c}\text { Mean } \\
\text { Score }\end{array}$ & $\begin{array}{c}\text { Standard } \\
\text { Deviation }\end{array}$ & Level \\
\hline 1 & Attitude & 3.91 & 0.41 & $\begin{array}{c}\text { Moderately } \\
\text { High }\end{array}$ \\
\hline 2 & Interest & 3.64 & 0.57 & $\begin{array}{c}\text { Moderately } \\
\text { High }\end{array}$ \\
\hline 3 & $\begin{array}{l}\text { Teachers } \\
\text { Guidance }\end{array}$ & 3.70 & 0.63 & $\begin{array}{c}\text { Moderately } \\
\text { High }\end{array}$ \\
\hline 4 & Peers & 3.46 & 0.51 & $\begin{array}{c}\text { Moderately } \\
\text { High }\end{array}$ \\
\hline 5 & Behaviour & 3.41 & 0.67 & $\begin{array}{c}\text { Moderately } \\
\text { High }\end{array}$ \\
\hline
\end{tabular}

Source: Output SPSS

\subsection{Research Question 2}

To what extent do attitude, interest, teachers' guidance and peers influence the entrepreneurial career intention behaviour among secondary school students in the Sepang district? 
A multiple regression analysis was used to answer the research questions and identify the influence of attitudes, interests, teaching of teachers and peers on entrepreneurial career intention behaviour. Several linear regression hypotheses such as variance equality test, normality test and collinearity were also conducted according to the recommendations by [74]. All these hypotheses are examined through a table of normal probability plots and distribution plots to ensure that the distribution of scores is normal and linear. This is to ensure that there is no violation of the prerequisites in the hypothesis that have been set.

The results of the analysis showed a significant variance value involving the attitudes, interests, teachers' guidance and peers in predicting the entrepreneurial career intention of students that is $\mathrm{F}=135.35, \mathrm{p}<0.00$ as shown in Table 2 . Table 3 describes the results of the multiple regression analysis for the variance value on entrepreneurial career intention behaviour related to the predictor domain which are attitude, interest, teaching of teachers and peers which is as much as 62.6 percent $\left(R^{2}=0.626\right)$.

Table 4 shows the variables of interest, teachers' guidance and peers which are the predictive variables of students' entrepreneurial career intention ( $p<0.05$ ). Attitude does not influence the choice of entrepreneurial career ( $p>0.05)$. Thus, to compare the influence of all these predictors, the value of $\beta$ in the Standard Coefficients is referred to. The findings of the analysis showed that interest has a greater influence which was 46.8 percent compared to the teaching of teachers (8.7 percent) and peers (36.1 percent). In this study, the domain of interest significantly influenced entrepreneurial career intention after influence from other variables in the model was controlled.

Table 2. Variance analysis of attitude, interest, teachers' guidance and peers

\begin{tabular}{crccccc}
\hline Model & & Total Squared & df & Mean Squared & F & Sig \\
\hline 1 & Regression & 91.361 & 4 & 22.840 & 135.348 & .00 \\
& Residual & 54.507 & 323 & .169 & & \\
& Total & 145.868 & 327 & & & \\
\hline
\end{tabular}

Predictor: Attitude, Interest, Teachers' Guidance and Peers

Dependent Variable: Behaviour of Entrepreneurial Career Intention

Table 3. Summary of standard Regression Analysis Model

\begin{tabular}{ccccc}
\hline Model & $\mathrm{R}$ & $\mathrm{R}^{2}$ & Adjusted $^{2}$ & Standard Error $^{2}$ \\
\hline 1 & 0.791 & 0.626 & 0.622 & 0.41079 \\
\hline
\end{tabular}

Table 4. Standard regression analysis of attitudes, interest, teachers' guidance and peers

\begin{tabular}{lcccccc}
\hline \multicolumn{1}{c}{ Predictor } & $\mathrm{B}$ & Standard Error & $\mathrm{t}$ & $\mathrm{Sig}$. & Beta & Influence Percentage $(\%)$ \\
\hline Attitude & -.016 & .067 & -.233 & .816 & -.010 & 1.0 \\
Interest & .550 & .059 & 9.405 & .000 & .468 & 46.8 \\
Teachers' Guidance & .092 & .042 & 2.170 & .031 & .087 & 8.7 \\
Peers & .468 & .061 & 7.624 & .000 & .361 & 36.1 \\
Constant variance & -.496 & .237 & -2.092 & .037 & & \\
\hline
\end{tabular}

Dependent variable: Behaviour of Entrepreneurial Career Intention 
Based on the multiple regression analysis above, it can be concluded that when the interest score increased per unit, the entrepreneurial career intention score increased by 0.468 units. The entrepreneurial career intention score increased by 0.087 units per unit increase of teachers' guidance score. Meanwhile, the entrepreneurial career intention score increased by 0.361 units per unit increase of peer score. However, as the attitude score decreased, the entrepreneurial career intention behaviour score increased.

Based on the statistical analysis above, a linear equation can be constructed i.e. entrepreneurial career intention behaviour:

$=-0.496+(-0.016) \mathrm{X} 1+0.550 \mathrm{X} 2+0.92 \mathrm{X} 3+0.468 \mathrm{X} 4$
Where;
Y=Entrepreneurial Career Intention Behaviour
$\mathrm{X} 1=$ Attitude
$\mathrm{X} 2=$ Interest
$\mathrm{X} 3=$ Teachers' Guidance
$\mathrm{X} 4=$ Peers
Constant
Variable=-0.496

This proves that interest $(\beta=0.468, p<0.05)$ is the best and most significant predictor compared to teachers' guidance $(\beta=0.087, \mathrm{p}<0.05)$ and peers $(\beta=0.361, \mathrm{p}<0.05)$ with an overall $\mathrm{R}^{2}=0.626$. On the other hand, attitude $(\beta=$ $-0.010, p>0.05)$ is not able to predict the entrepreneurial career intention behaviour of religious secondary school students in Sepang district, Selangor, Malaysia. This finding contradicts a study by [32]. In that study, it was found that entrepreneurial behaviour among community college students was largely influenced by attitude with a value of $R^{2}=0.67$ (67 percent). Ravi's [30] study also showed that attitude contributed a significant variant to entrepreneurship, i.e. 55.9 percent of influence towards entrepreneurial career intention behaviour. However, Fazlina [75] argues that attitude and interest are related to each other. Similarly, the findings of Iklima and Toh [76] found that MRSM students in Kuala Klawang, Negeri Sembilan, Malaysia have a high tendency towards entrepreneurship in terms of attitude and interest. Thus, a person's attitude towards something can change because it is influenced by what the person is exposed to and not from heredity or nature [77]. Students are not interested in entrepreneurial behaviour when they perceive that entrepreneurship is difficult. However, in this study, it is found that interest is the biggest influence on entrepreneurship, so this advantage is expected to be used to influence and develop an individual's attitude towards entrepreneurship even though attitude is relatively stable and difficult to change [78].

Research on the influence of interests, teachers' guidance and peers as a factor of predictor to entrepreneurial career intention is quite limited. However, a study by [18] found that interest was a significant factor in influencing students' entrepreneurial career intention with a value of 70.0 percent $\left(R^{2}=0.70\right)$. However, in this study, it is found that interest has the biggest influence on entrepreneurship, so the advantage is expected to be used to influence and develop individual attitudes even though attitudes are relatively stable and difficult to change [78, 80]. In addition, teachers' guidance has a value of $\left(\mathrm{R}^{2}=\right.$ $0.49)$ while peers have a value of $\left(\mathrm{R}^{2}=0.57\right)$. Studies related to the influence of peers towards the predictor of entrepreneurial factor are quite limited, but some studies can be used as a reference to identify the trend of peers acting as a predictor factor of entrepreneurial career intention among students.

\section{Conclusions}

This study strives to identify the level and influence of attitude, interest, teachers' guidance and peers on entrepreneurial career intention behaviour among religious secondary school students in Sepang, Selangor, Malaysia. This study found that the level of attitude, interest, teachers' guidance, peers and entrepreneurial career intention is at a moderately high level. These findings also explain that the domains of attitude, interest, teachers' guidance and peers have a significant influence on entrepreneurial career intention behaviour among students. Even though attitude had the highest score, the attitude domain was only able to be the lowest predictor of entrepreneurial career intention behaviour. The domain of interest is the best predictor of entrepreneurial career intention behaviour among students compared to teachers' guidance and peers. Attitude is not a good predictor for behaviour but it can change even though the process of change is quite complex and takes a long time.

The implication of this study is that it contributes to the applicability of the Theory of Planned Behaviour which explains that attitude, interest, teachers' guidance and peers act as predictors and affect the entrepreneurial career intention behaviour among students. These different domains contribute 62.6 percent to the overall model of this theory. Therefore, in practice, schools need to continue carrying out entrepreneurship programmes on a wider scale by involving the participation of successful local entrepreneurs as motivators for students to become entrepreneurs.

Overall, secondary school students were found to possess entrepreneurial behaviours. However, they need to be exposed to a variety of appropriate skills, knowledge and methods related to entrepreneurship education so that they can develop entrepreneurial thinking and attributes. It is hoped that quality entrepreneurship education as a result of effective and efficient guidance from teachers and positive peer influence can produce competent and courageous students with high leadership skills who can face and overcome the challenges of the business world. 


\section{Acknowledgements}

The author acknowledges the financial support from the Faculty of Education, Universiti Kebangsaan Malaysia, Grant GG-2019-036 and GGP-2017-066.

\section{REFERENCES}

[1] W. M. Z. Wan Nawang, I. Mamat. The Determinant Factors an Entrepreneurship Inclination among Secondary School Students. Akademika, Vol 89, No.2, 3-15, 2019.

[2] M. Radzi. Implementation of Entrepreneurial Sciences Thinking (EST) and its suitability in the context of education. Proceedings of the International Conference and Innovation Counselling and Education Innovation Competition 2013 Educational Diversity for Human Diversity. Batu Pahat: PERKAMA Consultants, 2013.

[3] W. M. Z. Wan Nawang. The Entrepreneurship Career Inclination in Terengganu Among the Members of Tunas Niaga Programme. Doctoral Thesis. Universiti Malaysia Terengganu, 2016a.

[4] N. H. Othman. Values and business ethics in Islam to form pious entrepreneurs. Proceeding Internatioanal Conference on Islamic Leadership -2 (ICIL), 2012.

[5] A. A. Manaf, N. H. Omar, L. K. Yee. Critical success factors among entrepreneurs in business. Journal of Social Science and Humanities, Vol 7, No. 1, 34-45, 2012.

[6] M. Z. Ibrahim. Relationship Between Entrepreneurship Self-Efficacy with Agro-entrepreneurial Intentions Among Agriculture Students. Master in Sciences. Universiti Putra Malaysia, 2014.

[7] The Companies Commission of Malaysia. Annual Report, 2017. Retrieved from https://www.ssm.com.my/ Pages/Publication/Annual_Report/PDF\%20File/SSM\%20 Annual\%20Report\%202017\%20(English\%20Version).pdf.

[8] S. Nadzri, N. Saleh, M. A. Mohd Buhary. Demographic Analysis of IPT Graduates in Entrepreneurship in Malaysia. Proceeding of the 2nd International Conference on Management and Muamalah. Malaysia, 2015.

[9] Bank Negara Malaysia Annual Report 2016. Retrieved from https://www.bnm.gov.my/files/publication/ar/en/2016/cp0 1.pdf.

[10] Graduate Tracking Study Report 2018. Educational Planning and Research Division, Ministry of Education Malaysia, First Publication on 2019.

[11] N. Othman, N. H. Othman, B.T Poo, R. Ismail. Impact of globalization and entrepreneurship career selection behavior among University students. Prosiding Persidangan Kebangsaan Ekonomi Malaysia ke VII (PERKEM), 2012.

[12] M. Sirat, A. A. Buang, M. Shuib, A. M. Mohd Isa, R. Bakar, A. Pandian, R. Mustafa, M. A. Abdullah, S. Abdul Rahman, M. D. Ibrahim, S. Z. A. Hamid, M. H. Piei, S. S. Ching Mey, N.N. Molly Lee, W. A. K. Mahmood. Unemployment problem among Penang graduates. Institut Penyelidikan Pendidikan Tinggi Negara, Universiti Sains Malaysia, 2004.
[13] N. Othman, H. Harun, Z.A. Lope Pihie, N. A. Buang. Entrepreneurial attitude index for teenagers in Malaysia. Final report project IRPA No. 07-02-02-0036 EA279, 2006.

[14] M.J. Mohd Nor, N. Hamzah, H. Basri, W.H. Wan Badaruzzaman. Outcome-based learning: principles and challenges. Post-Conference Teaching and Learning Seminar 2005, 54-62, 2006.

[15] A. B. Hamed, M. S. Bakar. Entrepreneurial personality and tendency to start a business: Comparison between Muslim and Non-Muslim students. Working Paper. Islamic Entrepreneurship Conference (ICEPS) di USIM, 16-17 Feb, 2008 .

[16] N. I. Khalid, S. Asimiran, Z. A. Lope Pihie. Readiness of vocational stream subject teachers to implement school enterprise programs in technical and vocational secondary schools. Jurnal Teknologi, 59(2012), 29-39, 2012.

[17] F. Lourenco, O. Jones. Developing entrepreneurship education: comparing traditional and alternative teaching approaches. International Journal of Entrepreneurship Education, 4(1), 111-140, 2006.

[18] N. Nasharudin, H. Harun. Entrepreneurial career aspirations among public institutions of higher learning students. Jurnal Pendidikan Malaysia, 35(1), 11-17, 2010.

[19] European Union National Commission Report. Entrepreneurship in the EU and beyond: A survey in the EU, EFTA countries, Croatia, Turkey, the US, Japan, South Korea and China. Flash Eurobarometer 283, The Gallup Organization, 2009.

[20] N. E. Abu, L.K. Eu. The relationship between attitudes, students' interest, teacher's instruction and peer influence on the achievement of Form 4 Additional Mathematics. Jurnal Kurikulum dan Pengajaran Asia Pasifik, 2 (1), 2014.

[21] W. M. Z. Wan Nawang, N. H. Sa'at, S. Ahmad, I. Mamat. Goodness of employment entrepreneurship as an intermediary link between predictive factors and student's intention to involves in the field of entrepreneurship career. Jurnal Sains Humanika, Vol. 8, No. 1, 23 - 29, 2016 b.

[22] S. P. Kalafatihan, M. Pollard, R. East, M. H. Tsogas. Green Marketing and Ajzen's theory of planned behavor: a cross - Market examination. Journal of Consumer Marketing, Vol. 16, No. 5, 441-460, 1999.

[23] D. D. Clercq, B. Honiq, B. Martin. The role of learning orientation and passion for work in the formation of entrepreneurial intention. International Small Business Journal, Vol. 31, No. 6, 652-676, 2013

[24] I, Z. Ertuna, E. Gurel. The moderating role of higher education on entrepreneurship. Education \& Training, Vol. 53, No. 5, 387-402, 2011.

[25] M. C. Sondari. Is entrepreneurship education really needed? Examining the antecedent of entrepreneurial career intention. Procedia- Social and Behavioral Sciences, 115, 44-53, 2014.

[26] F. Liñán, D. Urbano, M. Guerrero. Regional variations in entrepreneurial cognitions: start-up intentions of university students in Spain. Entrepreneurship and Regional Development, Vol. 23, No. 3\&4, 187-215, 2011. doi:10.1080/089856209 0323392 
[27] Z. Mohd Zain, A. Mohd Akram, E. K. Gani. Entrepreneurship intention among Malaysian business students. Journal Canadian Social Science, Vol. 6, No. 3, 34-44, 2010.

[28] M. S. Din, H. C. Hee, N. Hashim, O. Y. Keat, S. Ahmad, H. Bakar, N. Deraman, R. Mahmood, A. Mohamad, L.J. Abu Bakar, M. N. Md Hussain. Basic entrepreneurship. Kuala Lumpur, Prentice Hall, 2005.

[29] N. Othman, R. Hassan, W. M. D. Wan Zaki. Pendidikan Basic entrepreneurship. Universiti Kebangsaan Malaysia, 2017.

[30] Ravi a/l Nagarathanam. The relationship between attitudes, thoughts and behavior towards the desire in choosing the entrepreneurial career among the Indian undergraduates at the Institution of Higher Learning, Bangi. Master Thesis Education. Faculty of Education. UKM, 2015.

[31] A. Talib, H. Jusoh, Y. Ibrahim, H. Ahmad. Community participation in rural entrepreneurship: A study in Kubang Pasu District, Kedah, Prosiding PERKEM VII, JILID 2, 738-749, 2012.

[32] Z. Mustapha, M. Y. Tawang, A. H. Ahmad. Factors influencing entrepreneurial intentions among Malaysian Community College students. Journal of Social Sciences and Humanities, 1, 28-35, 2016.

[33] H. Hafidzin. A Study of Entrepreneurial Intention Among Commerce Students at SMK Seksyen 24(C) Shah Alam, Selangor. Master Thesis, Universiti Utara Malaysia, 2011.

[34] A. Azilahwati A. R. Syarizad, A. B. Muhammad Helmi. The tendency of Jasin Community College final year students towards entrepreneurship. Mini Education Seminar, 1-8, 2011.

[35] N. H. Md Nawi Teaching and learning: a review of basic concepts according to the perspective of the idea of Islamization of modern knowledge, In UKM Teaching and Learning Congress, 18-20 December, Hotel Vistana Penang, 2011.

[36] B. Hynes, Y. Costin, N. Birdthistle. Practice-based learning in entrepreneurship education: A means of connecting knowledge producers and users. Higher Education, Skills and Work-based Learning, Vol. 1, No. 1, 16- 28, 2011.

[37] K. Wennberg, D. Yar, H. Berglund. Creativity in entrepreneurship education. Journal of Small Business and Enterprise Development, Vol. 15, No.2, 304-320, 2008.

[38] R. Talip, M. Y. Abdullah, B. Mohamad, A. S. Ambotang, S. Zain, M. S. Taat. Teachers as agents of transformation in curriculum innovation. Minda Pendidik. Berita Harian, 23 April 2012.

[39] I. Ajzen, The Theory of Planned Behavior. Organizational Behavior and Human Design Process Vol. 50, No. 2, 179$221,1991$.

[40] R. Mohamad. Self-efficacy and entrepreneurial competence on the entrepreneurial tendencies of pre-university students. Master Thesis. Faculty of Education, UKM, 2017.

[41] W. Byabashaija, I. Katono. The impact of college entrepreneurial education on entrepreneurial attitudes and intention to start a business in Uganda. Entrepreneurship in
Africa Conference, Journal of Developmental Entrepreneurship, 2011.

[42] I. Ajzen, Nature and operation of attitudes. Annual Review of Psycology, Vol. 52, No.1, 27-28, 2001

[43] I. Ajzen, \& M. Fishben, The influence of attitudes on behaviour. Handbook of Attitudes and Attitude Change, Basic Principle, 173-221, 2005.

[44] N.F.J. Krueger, M.D. Reilly, A.L. Carsrud, Competing models of entrepreneurial intentions. Journal of Business Venturing, Vol. 9026, No.98, 411-432, 2000.

[45] N. F. Krueger, P. R. Dickson. How Believing in Ourselves Increases Risk Taking: Perceived Self-Efficacy and Opportunity Recognition. Decision Science, Vol. 25, No. 3, 385, 1994.

[46] R.V. Krejcie, \& D.W. Morgan. Determining sample size for research activities. Educational and Psychological Measurement, Vol. 30, 607 - 610, 1970.

[47] N. A. Buang, Y. P. Moi. Readiness of trade teachers in the Federal Territory from the aspect of knowledge of teaching methods and attitudes towards the teaching of Entrepreneurship Studies Subjects. Jurnal Teknologi, Vol. 37(E), 1-16, 2002

[48] R. Zaimah, S. Abdullah. The entrepreneurs' capability level in the Small and Medium Enterprises in Kuala Terengganu. Malaysian Journal of Science and Space, 13, 117-125. 2017.

[49] Q. M. Leng. Peer influence with mathematics achievement among Form 4 students in Batu Pahat district. Bachelor Thesis. Universiti Teknologi Malaysia, 2006

[50] N. A. Buang. Entrepreneurship education system in higher education institutions: A comparison between Malaysia and Thailand. Paper presented at $5^{\text {th }}$ comparative education society of Asia biennial conference 2005, organized by Universiti Kebangsaan Malaysia, 30-31 May, Bangi, 2005.

[51] N. A. Buang. Draft Instrumen Psikometrik Indeks Keusahawanan (PIKEN). Faculty of Education, Universiti Kebangsaan Malaysia, 2007.

[52] N. Aishah. Entrepreneurship Education, Universit Kebangsaan Malaysia 43600 Bangi Selangor Darul Ehsan, 2010.

[53] N. Othman. Effectiveness of adolescent entrepreneurship programs in secondary schools. Doctoral Thesis, Universiti Putra Malaysia, 2002.

[54] F. Rahimi, N. A. Buang. Comparison of the entrepreneurial attitude, source of encouragement, and self-efficacy toward entrepreneurial aspiration in student department of economic UKM, UPM and USIM. Journal of Global Business \& Social Entrepreneur (GBSE), Vol. 1, No.1, 29 $38,2017$.

[55] A. A. Safri, N. S. Atan. An Overview of Student Tendency Factors Towards Entrepreneurship: A Study in KUIS. Proceeding of the 5th International Conference on Management and Muamalah, 2018.

[56] A. Hassan \& N. A. Buang. Comparison the level of entrepreneurial attitude, thinking and behavior with business planning stage among Bachelor Degree in Science. Journal of Global Business \& Social Entrepreneur (GBSE), 
Vol. 1, No.1, 86-99, 2017.

[57] A. Bandura. Handbook of principles of organizational behaviour. 2nd Ed., New York, Wiley, 2009.

[58] R. B. Mustapha. Social Entrepreneurship in Indonesia and China: From Micro Credit to Community Development, 114, 2008. Retrieved from http://www.ufhrd.co.uk/wordpres s/wp- 14 content/uploads/2008/06/must-186-wp.pdf

[59] N. A. Buang. Entrepreneurship Education. Bangi: Universiti Kebangsaan Malaysia, 2013.

[60] R. Jusoh, N. Shahak. Teacher readiness for teaching and learning entrepreneurship education in primary schools. Prosiding Seminar Majlis dekan-dekan Pendidikan IPTA, 1325-1335, 2011.

[61] U. N. Saraih, A. Z. Zin Aris, S. Abdul Mutalib, T. S. Tunku Ahmad, M. H. Amlus. Examining the relationships between attitude towards behavior, subjective norms and entrepreneurial intention among engineering students. MATEC Web of Conferences, 150, 05011, 2018. https://doi.org/10.1051/matecconf/201815005011

[62] Z. Ishak. Entrepreneurial science thinking: Readiness to integrate entrepreneurial thinking in science teaching at Maktab Rendah Sains MARA. Doctoral Thesis, Universiti Kebangsaan Malaysia, Bangi, 2013.

[63] E. Abaho, D. R. Olomi, G. C. Urassa. Students' entrepreneurial self-efficacy: Does the teaching method matter? Education \& Training, Vol. 57 Issue: 8/9, 908-923, 2015.

[64] A. R. Rafiza, A. R. Maryam. Development of multimediabased instructional media among among ICTL Teachers. Jurnal Kurikulum \& Pengajaran Asia Pasifik, 1, 20-31, 2013.

[65] R. Zamuddin, S. Sidek, N. Abu Bakar. Factors Influencing the Interest of Final Year Students in Entrepreneurship in UTM.Bachelor Thesis, UTM. 2008.

[66] W. M. Z. Wan Nawang, I. Mamat, N. H. Sa'at, S. Ahmad. The role of demographic variables in predicting the tendency of Program Tunas Niaga members to venture into entrepreneurial careers. Journal of Holistics Students Development, Vol. 1, No. 1, 12-29, 2016.

[67] F. R. Pamela. Determinants of entrepreneurial attitudes and intentions among high school students in Iligan City, Southern Philippines. Proceeding $2^{\text {nd }}$ International Conference on Entrepreneurship. Vistana Hotel, Kuala Lumpur, 2010.

[68] Z. A. Lope Pihie, A. Bagheri. Malay student's entrepreneurial attitude and entrepreneurial efficacy in vocational and technical secondary schools of Malaysia. Pertanika Journal of Social Sciences and Humanities, Vol. 19, No.2,433-447, 2011.

[69] I. Murni. Entrepreneurial thinking and behavior in recognizing business opportunities among IPT students in Padang Sumatera Barat, Indonesia. Doctoral Thesis, Universiti Kebangsaan Malaysia, 2012.

[70] J.C. Sanchez, T. Caballo, A. Gutierrez. The entrepreneur from a cognitive approach. Psicothema, Vol. 23, No. 3, 433438, 2011.

[71] I. M. Krecar, G. Coric. Changes in Entrepreneurial SelfEfficacy since Completion of Entrepreneurial Studies. Procedia - Social and Behavioral Sciences, 89, pp. 74-78, 2013. https://doi.org/10.1016/j.sbspro.2013.08.812

[72] D.A. Kirby. Entrepreneurship education: can business schools meet the challenge? Education + Training, Vol. 46, No. 8/9, 510-519, 2004.

[73] M. Mansor, N. Othman. Consulting-based entrepreneurship education in Malaysian higher education institutions. International Conference on Social Science and Humanity, IACSIT Press, Singapore, 5(November), 351-355, 2011.

[74] J. Pallant. SPSS Survival Manual: A Step by Step Guide to Data Analysis using SPSS. England, 2010.

[75] F. A. Rahiman, A.S.A Shukor. Relationship of interest and attitude towards student achievement in the course DPA3043 - auditing. National Innovation and Invention Competition Through Exhibition (iCompEx'17), 2017.

[76] I. H. Abdul Rahim, T. P. Sung. Effectiveness of Entrepreneurship Camp towards MRSM Students. Journal of Humanities, Language, Culture and Business (HLCB), Vol. 3, No.12, 105-114, 2019.

[77] A. Hassan, A. Mohd. The power of influence and change of attitude. Kuala Lumpur: Utusan Publications and Distributors Sdn. Bhd., 1997.

[78] B. Kemat. Entrepreneurial Attitude Orientation Among Polytechnic Students in Malaysia. Master Thesis in Administration. Universiti Utara Malaysia, 1994.

[79] V. Johansen, Entrepreneurship education and academic performance. Scandinavian Journal of Educational Research, Vol. 58, No.3, 300-314, 2014.

[80] F. Zorlu, Y. Zorlu. Comparison of science process skills with stem career interest of middle school students. Universal Journal of Educational Research 5(12): 21172124, 2017. Available from https://doi.org/10.13189/ujer.2017.051201. Accessed date 28.09.2020. 